\title{
Records of Microlepidoptera from Finland 1989 (Lepidoptera)
}

\author{
Sakari Kerppola \\ Hiihtomäentie 44 A 6, SF-00800 Helsinki, Finland
}

This article is a short summary of the records published in the Finnish Lepidopterological Society's journal Baptria (Kerppola et al. 1991) in which are to be found much more data and many more details of Finnish Microlepidoptera in previous annual reports dating back to 1984 .

The article reports interesting Finnish Microlepidoptera collected in 1989, as well as interesting findings of specimens collected in previous years and not reported or definitely identified until 1989. The classification and nomenclature follow the Check-list of Finnish Lepidoptera (Varis et al. 1987).

Species new to the Finnish fauna are: Trifurcula subnitidella (Duponchel, 1843) and Bucculatrix latviaella Šulcs, 1990. One species, Pristerognatha penthinana (Guenée, 1845), is omitted from the Finnish list because of misidentification. A hitherto unknown foodplant is reported for Strophedra nitidana (Fabricius, 1794). At present, 1421 species of Microlepidoptera are known from Finland.

\section{Nepticulidae}

Trifurcula subnitidella (Duponchel, 1843)

Ka: Virolahti 670:53, 20.6.1989, 1 ex. and 28-29.6.1989, 46 exx., Jari-Pekka Kaitila leg. (Sakari Kerppola det.). The species is new to the Finnish fauna.

The morphology, biology and distribution are fully described by Johansson et al. (1989). This Finnish find is not included in this book. The find is the most northern recorded in Europe and never before have so many specimens been caught in one place. The place where they are found is near the Russian border on the sea-shore by the Gulf of Finland. The vegetation in this place is mainly low grasses with plenty of Lotus corniculatus L., which is the foodplant of T. subnitidella. The moths were caught with a net, by sweeping the vegetation in the evening between 1900 and 2100 .

The systematic position in the Finnish list is after Trifurcula headleyella (Stainton, 1854).

\section{Bucculatricidae}

Bucculatrix latviaella Šulcs, 1990

Sa: Punkasalmi, 27.06.1933, E. Lindeberg leg. The species is new to the Finnish fauna.

During his visit to Finland in 1989, Dr. Ivars Sulcs identified one male of this moth in the collection of Prof. Harry Krogerus (Šulcs, 1990). The habitus and genitalia are very close to those of Bucculatrix maritima Stainton, 1851. The location in which they are found is in eastern Finland about $170 \mathrm{~km}$ north of the coast. In this place Aster tripolium L. (which is the foodplant of B. maritima) is not to be found. B. latviaella has formerly been found only in Lettland.

The systematic position in the Finnish list is after Bucculatrix maritima.

\section{Tortricidae}

Pristerognatha penthinana (Guenée, 1845)

This moth has a long history in Finland. One female was caught by Mr. J. Alvas 20.7.1958 in N: 
Porvoo, Pellinge which is an archipelago area about $50 \mathrm{~km}$ east of Helsinki. The species was originally determined as Arcyroploce flavipalpana (Herrich \& Schäffer, 1848) and later it was redetermined as Pristerognatha penthinana (Guenée, 1845) (Kerppola et al. 1987).

Last spring my friend Mr. Jari Junnilainen and I collected many Pristerognatha-larvae from Impatiens nolitangere L. - near the place where the 1958 moth was caught. The rearing was successful and about 50 specimens emerged. They were all Pristerognatha fuligana (Denis \& Schiffermüller, 1775) and this was the reason for the re-examination of the 1958 moth. When I made comparisons between this specimen's genitalia (female) and the reared $P$. fuligana specimens I was unable to see any particular differences. I also made a comparison with one female of true $P$. penthinana (which is in the Palaearctic collection in the Mus. Zool. Helsinki, Jorma Kyrki det.) and I found a significant difference in the ostium.

I think the 1958 moth from Porvoo was $P$. fuligana, but due to the lack of $P$. penthinana material and poor figures of the female genitalia in the literature I was still slightly uncertain of my identification. I sent the moth to Dr. Ole Karsholt (Copenhagen, Denmark) so that he could confirm my identification and he agreed with me. Hence, $P$. penthinana will be omitted from the Finnish fauna.
Strophedra nitidana (Fabricius, 1794)

Kb: Kitee 687:66, 1989, ex larva, 1 ex., L. Sippola \& E. Saarela leg.

This species was reared in Finland for the first time and a new foodplant was also recorded. One larva was found in the autumn of 1988 living between two leaves of Betula pubescens Ehrh. The moth emerged successfully. The species was previously known as monophagous on Quercus L.

Acknowledgements. Thanks are due to the above mentioned Finnish entomologists. My special thanks also go to Dr. Erik J. van Nieukerken (Leiden, The Netherlands) and Dr. Ole Karsholt (Copenhagen, Denmark) for their valuable help in identification.

\section{References}

Johansson, R., Nielsen, E. S., van Nieukerken, E. J. \& Gustafsson, B. 1989: The Nepticulidae and Opostegidae (Lepidoptera) of North West Europe. - FaunaEntomol. Scand. 23:1-739.

Kerppola, S., Kontuniemi, I. \& Löfgren, L. 1987: Records on Finnish Microlepidoptera 1986. (In Finnish with English summary). — Baptria 12:63-72

- 1991: Records on Finnish Microlepidoptera 1989. (In Finnish with English summary) — Baptria 16:(in press).

Šulcs, I., 1990: Bucculatrix latviaella sp. n. aus Lettland (Lepidoptera, Bucculatricidae). - Entomol. Fennica 1:41-44.

Varis, V., Jalava, J. \& Kyrki, J. 1987: Check-list of Finnish Lepidoptera / Suomen perhosten luettelo. - Notulae Entomol. 67:49-118.

Received 12.II.1991 